Original Research Paper

\title{
Budidaya Ikan dan Sayur Untuk Optimalisasi Pemanfaatan Pekarangan Rumah di Keluarahan Rabangodu Utara Kecamatan Raba Kota Bima
}

\author{
Nur Istiqomah ${ }^{1 *}$, Sri Kurniati ${ }^{2}$ \\ ${ }^{I}$ Program Studi Pendidikan Guru Sekolah Dasar, Fakultas Keguruan dan Ilmu Pendidikan, Universitas Mataram, Mataram, \\ Indonesia \\ ${ }^{2}$ Program Studi Pendidikan Anak Usia Dini, Fakultas Keguruan dan Ilmu Pendidikan, Universitas Mataram, Mataram, \\ Indonesia
}

DOI: https://doi.org/10.29303/jpmpi.v3i2.536

Sitasi: Jariyah, A., Hairnisa, \& Mariati (2020). Budidaya Ikan dan Sayur Untuk Optimalisasi Pemanfaatan Pekarangan Rumah di Keluarahan Rabangodu Utara Kecamatan Raba Kota Bima. Jurnal Pengabdian Magister Pendidikan IPA, 4(1)

\section{Article history}

Received: 10 Desember 2020

Revised: 30 Desember 2020

Accepted: 07 Januari 2020

*Corresponding Author: Ainun Jariyah, Program Studi Pendidikan Guru Sekolah Dasar, Fakultas Keguruan dan Ilmu Pendidikan, Universitas Mataram, Mataram, Indonesia Email:

hairunisanysa@gmail.com

\begin{abstract}
Budidaya Ikan dan Sayur dalam Ember merupakan program pengembangan dari aquaponik, yang mana ikan dan tanaman dapat tumbuh dalam satu wadah. Budidaya Ikan dan Sayur dalam Ember menjadi solusi potensial bagi budidaya perikanan dan pertanian di lahan yang sempit dengan penggunaan air yang lebih hemat, mudah dilakukan oleh masyarakat di rumah masing-masing dengan modal yang relatif kecil. Tujuan dari kegiatan ini untuk menumbuhkan minat masyarakat dalam melakukan budidaya ikan dan sayuran dalam satu tempat, sehingga hasil panen yang didapat pun berlimpah serta mencukupi kebutuhan gizi yang berasal dari ikan dan sayuran. Kegiatan ini dilakukan dalam dua tahap yaitu tahap awal berupa pengumpulan data dengan cara dokumentasi foto dan pendekatan dengan tokoh masyarakat dan pemangku kepentingan, tahap kedua yaitu pelaksanaan dengan cara sosialisasi kemudian mulai melaksanakan kegiatan budidaya ikan dan sayur dalam ember kepada masyarakat setempat. Manfaat yang didapat dengan mempraktikkan budidaya ikan dan sayur dalam ember di antaranya menyediakan pangan keluarga dengan protein hewani dan sayuran dalam kondisi sehat dan segar. Hasil yang didapatkan dari program ini adalah adanya peningkatan pengetahuan dan ketrampilan mitra tentang budidaya ikan dan sayur dalam ember serta adanya peningkatan kemandirian pangan keluarga dengan memanfaatkan pekarangan rumah melalui budidaya sayuran dan ikan dalam satu tempat.
\end{abstract}

Keywords: Budikdamber, Akuaponik, Lahan Sempit, Kelurahan Rabangodu Utara

\section{Pendahuluan}

Budidaya ikan dan sayur didalam ember dengan sistem Akuaponik merupakan gabungan dari sistem budidaya ikan (akuakultur) dengan tanaman (hidroponik) dalam wadah budidaya berupa ember (Arif 2020). Budidaya ikan dalam ember atau yang kerap disebut Budikdamber merupakan salah satu solusi pangan masa depan yang bisa dikembang di lahan terbatas untuk menciptakann kemandirian pangan masyarakat terutaman di masa pandemi Covid-19 seperti saat ini (2020). Dengan teknik budidaya ikan dalam ember, masyarakat tak perlu lagi cemas akan pemenuhan kebutuhan protein hewani dan sayuran bagi keluarga (2020). Terlebih saat ini Presiden Joko Widodo meminta semua lapisan masayrakat untuk menerapkan pola adaptasi baru di tengah pandemi virus Corona (Covid19) yang disebut New 
Normal (Rizky 2020). New Normal merupakan Kehidupan normal baru dimana masyarakat diizinkan untuk melakukan aktivitas seperti biasa, namun dengan tetap mematuhi protokol kesehatan yang selama ini berlaku (2020). Mayarakat dituntut untuk tetap produktif di era new normal.

Program pengabdian Kuliah Kerja Nyata (KKN) di Kelurahan Rabangodu Utara ini difokuskan pada Peningkatan pengetahuan dan keterampilan masyarakat Kelurahan Rabangodu Utara untuk tetap produktif dengan cara Budidaya Ikan dan Sayur dalam Ember dengan Sistem Aquaponik (Budidaya Ikan dan Sayur dalam Ember) sebagai solusi ketersediaan bahan pangan dan nutrisi bagi keluarga di tengah pandemi Covid19.

Budidaya ikan dan sayur tidak membutuhkan modal yang mahal. Seluruh peralatan yang dibutuhkan dalam kegiatan budidaya ikan dan sayur dalam ember adalah murah, dapat di jangkau. Jadi semua orang dapat melakukannya. Seorang pembudidaya pasti menginginkan tempat budidayanya yang mudah di jangkau karena mempermudah dalam hal pengontrolan. Kegiatan Budidaya Ikan dan Sayur dalam Ember dapat dilaksanakan di pekarangan rumah sehingga mempermudah dalam hal pengontrolan. Salah satu kelebihan dari Budidaya Ikan dan Sayur dalam Ember adalah dapat membudidayakan dua komoditas sekaligus yaitu ikan dan sayuran, sehingga dapat memanen dua komoditas secara bersamaan atau bergantian. Seperti halnya sayuran kangkung dan sawi. Kangkung dapat dipanen saat sudah masanya dengan memotong bagian batang sehingga nantinya muncul batang yang baru, jadi proses pemanenannya berkelanjutan.

Tujuan dari program Budidaya Ikan dan Sayur dalam Ember dengan sistem Akuaponik adalah penyediaan bahan pangan dan nutrisi sebagai salah satu bentuk dari ketahanan pangan keluarga di tengah pandemi Covid-19.

Manfaat dari program ini adalah masyarakat yang tinggal di daerah kelurahan Rabangodu Utara dapat memanfaatkan lahan pekarangan yang tidak terlalu luas untuk membudidayakan ikan sekaligus bercocok tanam dengan Teknik Budidaya Ikan dan Sayur dalam Ember.

\section{Metode}

Waktu dan tempat Program ini dilakukan di kelurahan rabangodu selatan Kecamatan Raba, Nusa Tenggara Barat pada bulan November-Januari 2020.

Adapun metode pelaksanaan kegiatan pengabdian ini menggunakan metode pendekatan secara langsung, yang dikemas dalam bentuk sosialisasi dan praktik. adapun tahap-tahap pelaksanaannya meliputi :

1. Waktu dan Tempat

Program pengabdian masyararakat mengenai "Budidaya Ikan dan Sayur Untuk Optimalisasi Pemanfaatan Pekarangan Rumah di Keluarahan Rabangodu Utara Kecamatan Raba Kota Bima" dilakukan pada Bulan November 2 s/d Januari 2021 di Kel. Rabangodu Utara Kec. Raba Kota Bima.

2. Alat dan Bahan

Alat dan bahan yang dibutuhkan dalam program ini berupa ember ukuran 80 liter dan 50 liter, benih ikan lele, bibit kangkung, bibit sawi, gelas pop ice/aqua, arang, pipa, kawat jarring, pakan ikan, rock wol, serokan ikan dan solder.

3. Bentuk Kegiatan

a. Tahap Awal

Tahap awal dalam kegiatan ini adalah observasi langsung dengan cara diskusi langsung dengan ketua RW dan ketua RT serta mewawancarai beberapa warga terkait minat dalam kegiatan Budikdamber. Setelah melakukan wawancara kemudian dlanjutkan dengan survei lokasi untuk lahan penyimpanan ember budidaya ikan dan sayur dalam ember. Metode pengumpulan data yang digunakan adalah dokumentasi dan pendekatan dengan tokoh masyarakat dan pemangku kepentingan.

b. Tahap Pelaksanaan

Tahap selanjutnya adalah tahap pelaksanaan dengan mengidentifikasi dan menganalisis data hasil obeservasi dan diskusi dari tahap pertama untuk pengembangan solusi. Pengembangan solusi yang dapat dilakukan atas permasalahan yang timbul ditengah masyarakat atas pemanfaatan pekarangan rumah terhadap ketersedian pangan/kebutuhan pokok seharihari adalah pendampingan masyarakat dengan Budidaya 
Ikan dan sayur dalam Ember sebagai solusi ketahan pangan bagi keluarga. Dalam program ini kami bagi menjadi 2 kegiatan. Kegiatan pertama adalah sosialisasi atau memberikan gambaran umum kepada masyarakat yang berada di desa setempat mengenai Budidaya Ikan dan Sayur dalam Ember dengan Sistem Aquaponik (Budidaya Ikan dan Sayur dalam Ember). Pelatihan ini dikhususkan pada masyarakat yang sudah berkeluarga. Kegiatan kedua adalah pelaksaan Budidaya Ikan dan Sayur dalam Ember dengan Sistem Aquaponik (Budikdamber) kepada masyarakat setempat. Adapun tahaptahap yang akan dilakukan meliputi:

\section{Metode}

Program ini menggunakan metode kualitatif dengan pendekatan kualitatif deskriptif karena mampu menyajikan gambaran secara detail tentang situasi, pada umumnya merupakan data yang dikumpulkan berupa kata-kata, Gambar dan bukan angka. Pengambilan data pada program ini dilakukan dengan tekhnik observasi lapangan, wawancara dan studi pustaka yang selanjutnya dianalisis dengan

\section{Hasil dan Pembahasan}

Program edukasi masyarakat dalam pemanfaatan lahan di kelurahan Rabangodu Utara dalam program Budidaya Ikan dan Sayur dalam Ember dilakukan secara terstruktur dan melibatkan masyarakat secara langsung seperti Ketua RW/RT, pemuda dan warga kelurahan Rabangodu Utara Secara umum.

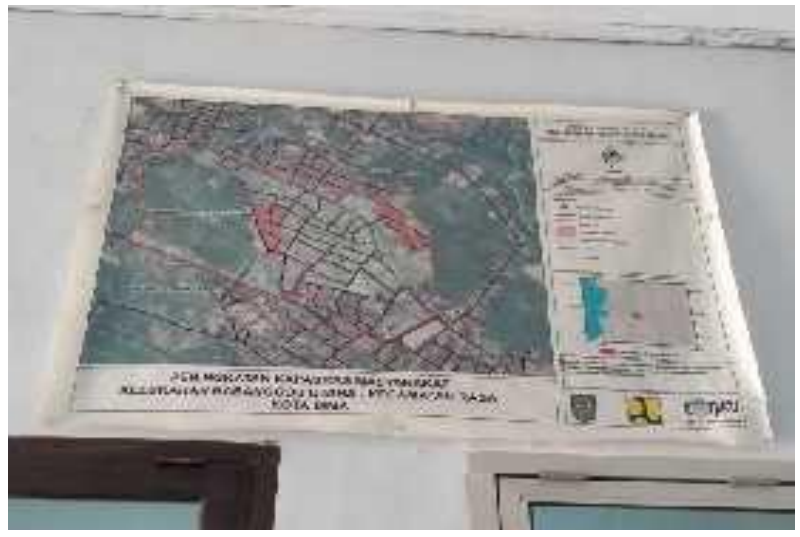

Gambar 1. Peta Denah Daerah Lingkungan

Kec. Rabangodu Utara a. Persiapan Alat dan Bahan

Tahap pertama dalam kegiatan Budidaya ikan dan sayur dalam ember adalah persiapan alat dan bahan. Alat dan bahan ini difasilitasi oleh teman-teman mahasisiwa, termasuk penulis (peserta $\mathrm{KKN}$ ). Adapun alat dan bahan yang diperlukan meliputi :

- Ember 80 dan $50 \mathrm{~L}$

- Benih ikan lele

- Benih/bibit kangkung dan Sawi

- Gelas plastik ukuran sedang

- Arang kayu dan rockwol

- Serokan ikan

- Kawat jaring sebagai penutup bagian lubang pada ember

- Pipa pembuangan air

- Solder

- Pakan Lele

\section{Bahan-Bahan}
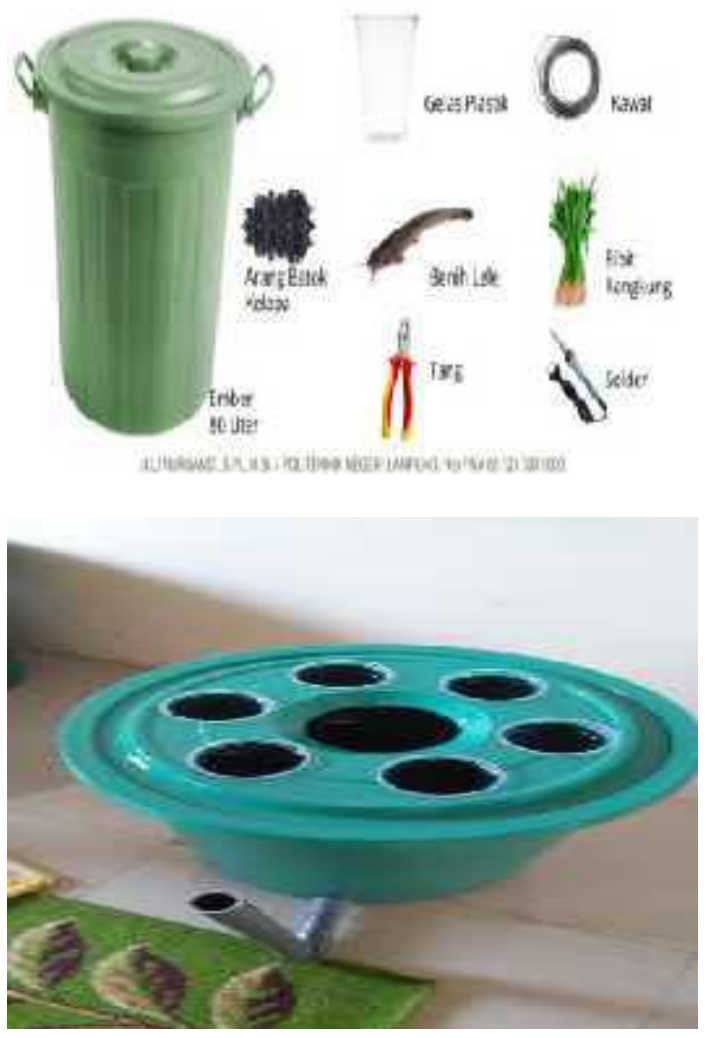

Gambar 2. Alat dan Bahan 
b. Pembuatan media Budidaya ikan dan sayur dalam ember

Tahap selanjutnya adalah tahap pembuatan media Budidaya Ikan dan Sayur dalam Ember. Media Budidaya Ikan dan Sayur Dalam Ember berupa ember (ukuran 80 dan 50 liter) yang kemudian tutupan ember 80 liter dilubangi 6 lubang dan tutupan ember 50 liter dilubangi 4 lubang untuk tempat sirkulasiudara ikan lele. Gelas plastik (ukuran sedang ) digunakan sebagai wadah untuk budidaya kangkung yang kemudian dilubangi pada bagian samping dan bawah gelas menggunakan solder dan tidak lupa dibagian bawah ember diberi tempat pembuangan air menggunakan pipa air yang dipasang dengan cara melubangi bagian bawah ember dengan solder. Pada bagian tengah atas ember dipasang kawat jaaring agar ikan lele tidak loncat keluar.
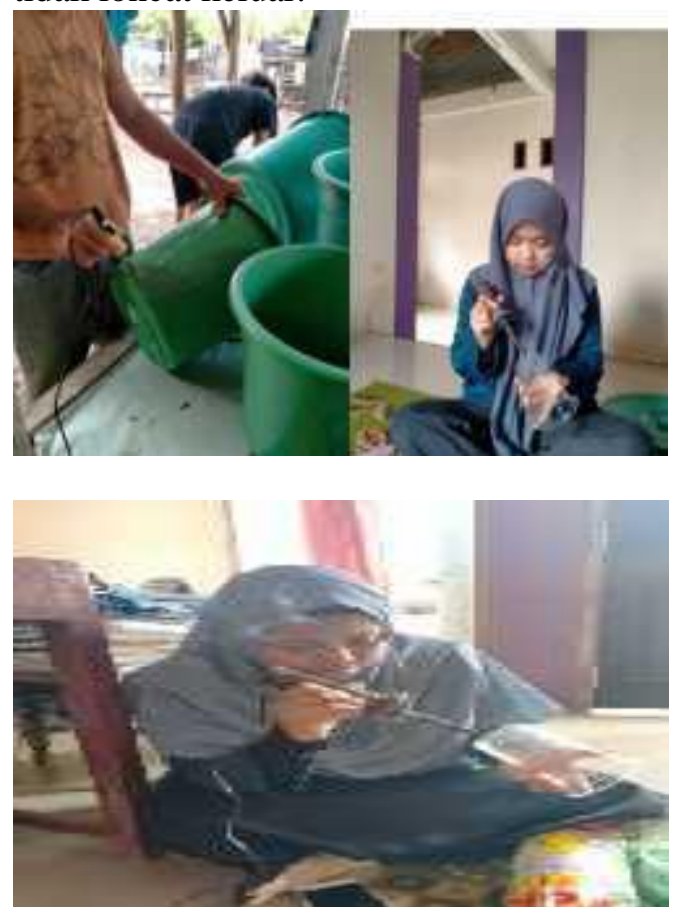

Gambar 3. Proses perakitan media Budidaya Ikan dan Sayur dalam Ember

\section{c. Sosialisai}

Kegiatan Sosialisasi dilakukan di salah satu musola setempat yang berada tidak jauh darirumah warga, kami melaksanakan sosialisai pada tanggal 04 desember 2020 dan kegiatan ini berlangsung selama kurang lebih 30 menit dari jam 15.00 s/d 17.00 WITA Dalam kegiatan sosialisasi ini kami khususkan Ibu rumah tangga. Sosialisasi yang diberikan diataranya meliputi penjelasan mengenai budidaya ikan dan sayur dalam ember dengan system aquaponik (Budikdamber) terhadap ketahan pangan keluraga, keunggulan budidaya ikan dan sayur dalam ember, tujuan, serta manfaat Budidaya Ikan dan Sayur dalam Ember di tengah pandemic Covid-19.
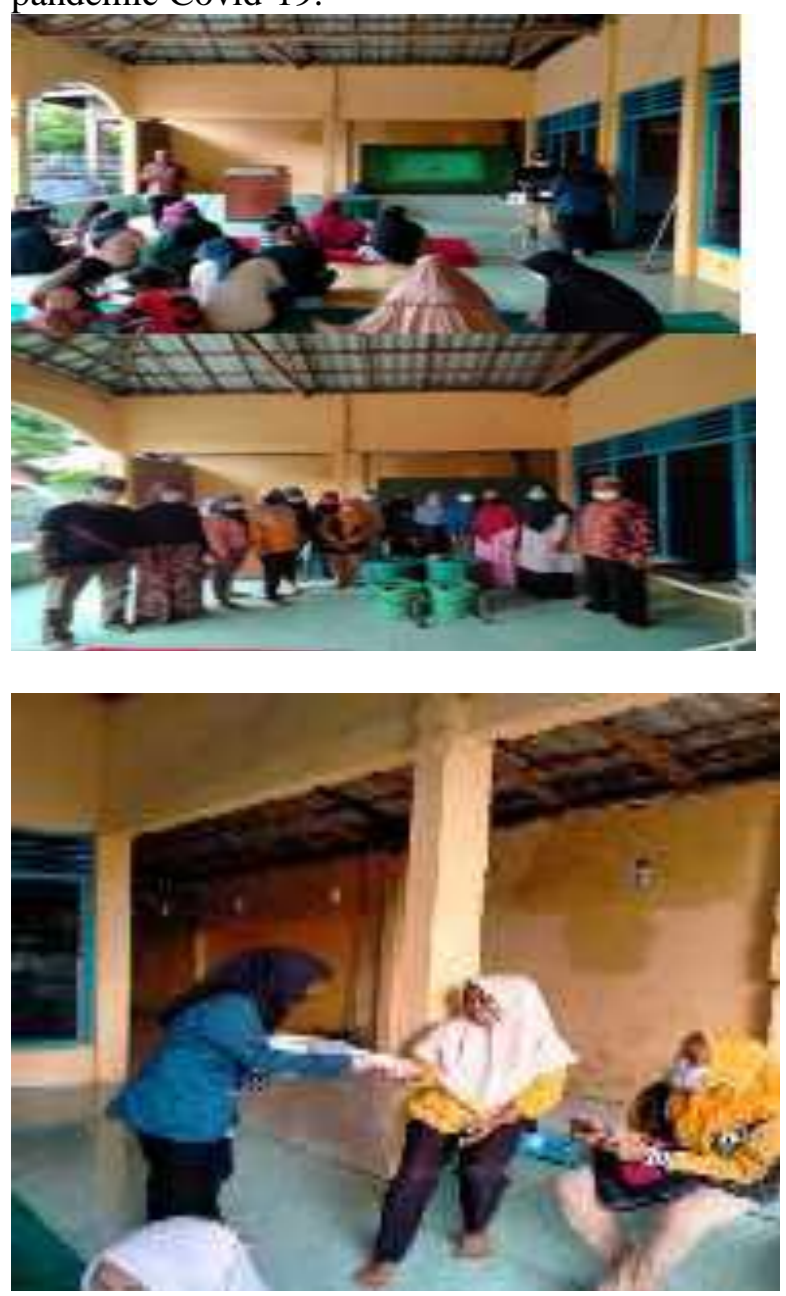

Gambar 4. Sosialisasi dan pembagian masker serta penyerahan ember pada warga

d. Penyemaian Bibit Kangkung dan Sawi

Pada tahap ini benih di kecambahi secara bersamaan dengan menggunakan wadah gelas plastic sebagai medianya. Usahakan agar rockwol tidak kering dan tetap lembab agar proses perkecambahan berhasil. 

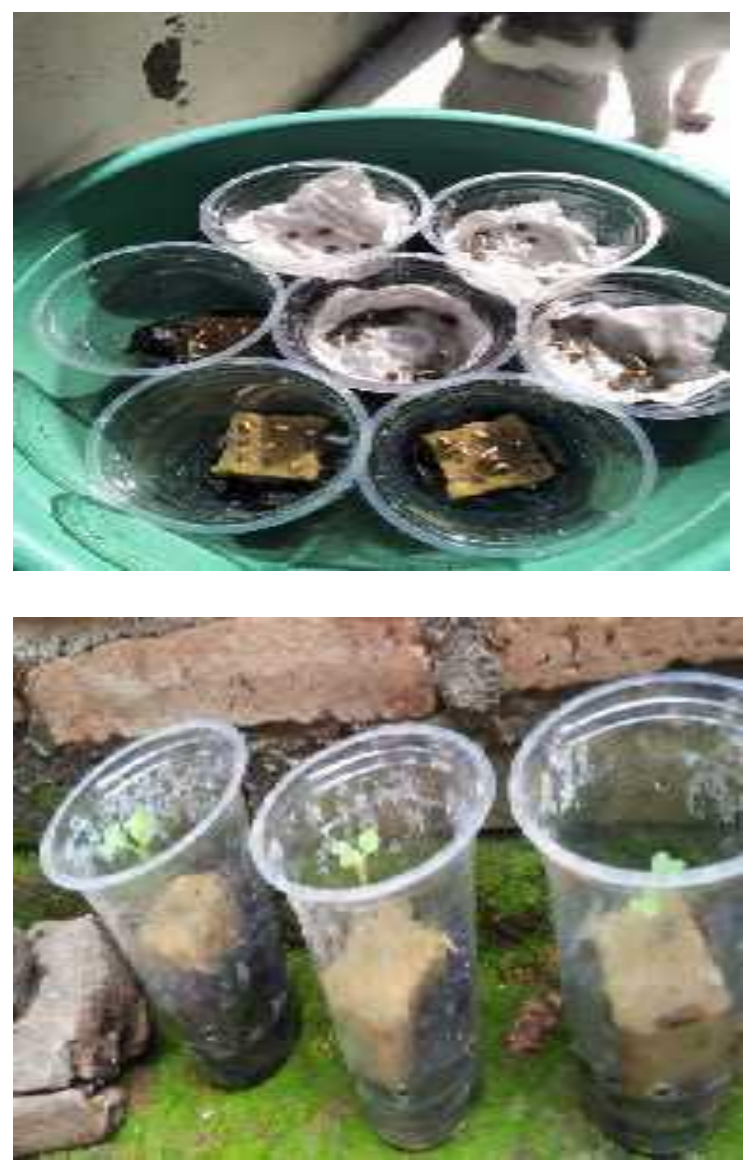

Gambar 5. Penyemaian Bibit Kangkung dan Sawi

e. Penebaran Bibit Lele

Tahap yang dilakukan selanjutna adalah tahap Penebaran Bibit Lele. Ember 80 liter diisi air setinggi leher ember yang sebelumnya sudah didiamkan selama 4 hari dan tidak lupa diberikan larutan EM4 (effective microorganisme) untuk meningkatkan mutu air dan menekan bakteri jahat agar ikan terhidar dari penyakit. Semakin lama air yang diendapkan maka semakin bagus pula kualitas airnya. Kemudian dilakukan pengisian bibit lele ke dalam ember yang sudah disiapkan. Setiap ember diisi sekitar 50-100 ekor bibit lele.
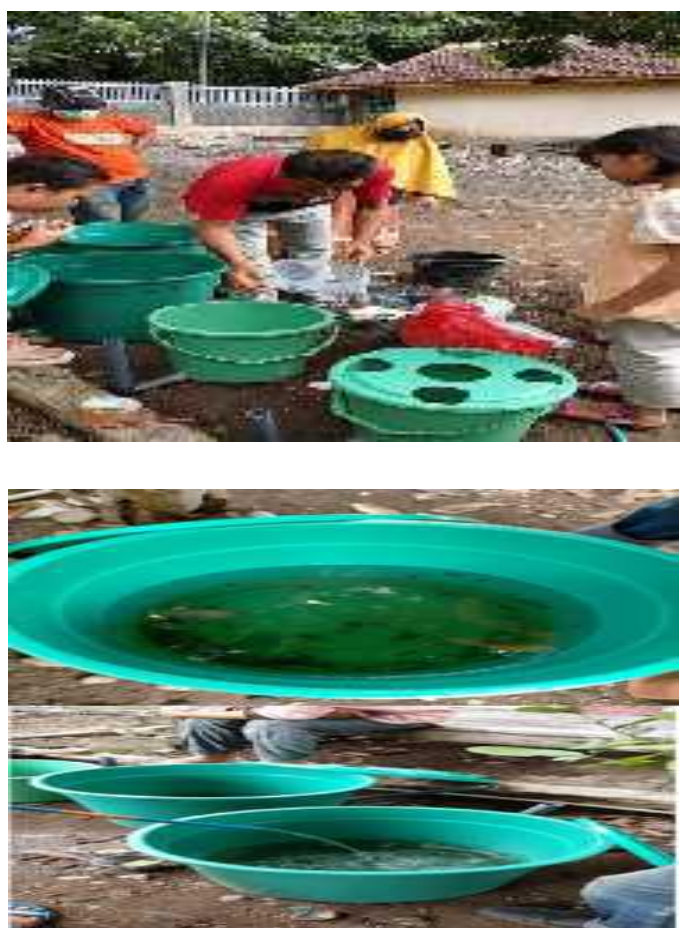

Gambar 6. Penebran Benih Lele

f. Pemeliharaan Budidaya Ikan dan Sayur Dalam Ember

Tahap yang dilakukan setelah penebaran bibit lele dan penanaman bibit kangkung adalah tahap pemeliharaan. Ada beberapa prosedur yang harus diperhatikan pada saat pemeliharan berlangsung. Ember diletakkan ditempat yang terkena matahari maksimal. Menurut (Nursandi) Bila ada kutu di daun kangkung segera buang daun atau batang karena kangkung akan kriting dan mati. Berikan pakan kepada ikan secukupnya atau sesuai ukuran sekenyangnya, bias dilakukan sebanyak 2-3 kali sehari (lele dengan ukuran 5-7 $\mathrm{cm}$ pakan pf800, $10 \mathrm{~cm}$ pf1000, > $12 \mathrm{~cm} \mathrm{781-2,781-1,781).} \mathrm{Bila} \mathrm{nafsu}$ makan ikan menurun, air berbau busuk, dan ikan menggantung (kepala di atas dan ekor dibawah), lakukan pergantian air tau sipon (penyedotan kotoran di dasar ember dengan selang atau menggunakan kran air) biasanya dilakukan 1014 hari, penyedotan 5-8 liter air, bisa lebih atau keseluruhan bila perlu, kemudian ganti dengan air bersih. Limbah air tidak dibuang begitu saja, namun dimanfaatkan kembali sebagai pupuk bagi tanaman-tanaman dengan cara disiramkan, sehingga tidak terbuang dengan percuma. Lakukan penyortiran ikan lele setiap sebulan 
sekali sesuai ukurannya, agar ikan lele yang ukurannya kecil tidak dimakan oleh ikan lele yang ukurannya lebih besar atau kanibal.

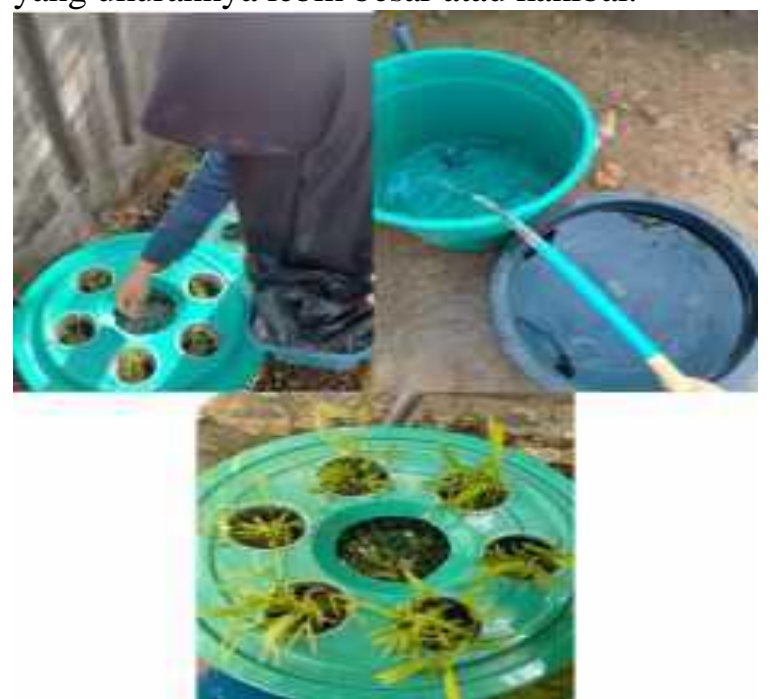

Kangkung

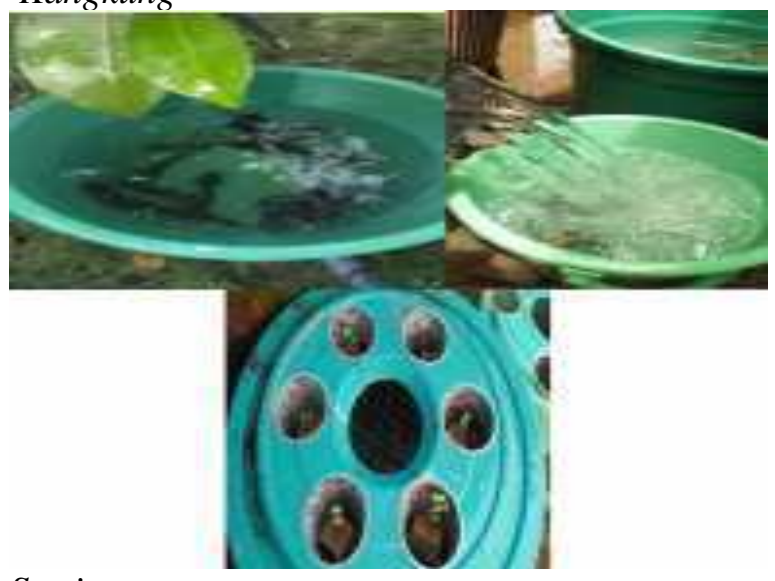

Sawi

Gambar 7. Pemberian pakan Lele dan Penggantian Air secara berkala

g. Tahap Pemanenan

Tahap yang paling ditunggu-tunngu pada program ini adalah tahap panen. Penen kangkung pertama sekitar 14-21 hari sejak tanam. Sisakan bagian bawah atau tunas kangkong untuk pertumbuhan kembali, panen kedua dan selanjutnya berjarak 10-14 hari sekali. Jumlah panen kangkung akan berkurang ketika sudah memasuki bulan ke-3 dan ke-4 pemeliharaan. Ketika jumlah panen kangkung sudah mulai berkurang bisa dilakukan penanaman kembali melalui pergantian kangkung dengan bibit baru.
Ikan Lele sudah biasa dipanen kira-kira sekitar 1,5-2 bulan masa pemeliharaan. panen ikan lele tidak dilakukan secara serentak untuk seluruh ember, karena besar ikan lele tidak seragam untuk pemelihraan selama satu setengah bulan tersebut. Ikan yang pertama kali dipanen adalah ikan yang ukurannya $>17 \mathrm{~cm}$. Bulan berikutnya sampai bulan ke- 4 pemeliharaan juga bisa dilakukan panen ikan karena ikan yang di awal panen masih berukuran < $17 \mathrm{~cm}$ sudah bisa mencapai ukuran tersebut di bulan-bulan berikutnya (susetya 2018).

\section{Kesimpulan}

Kegiatan pengabdian masyarakat tentang Budidaya Ikan dan Sayur Untuk Optimalisasi Pemanfaatan Pekarangan Rumah di Keluarahan Rabangodu Utara Kecamatan Raba Kota Bima dapat peningkatan pengetahuan dan keterampilan masyarakat khususnya yang sudah berkeluarga untuk tetap produktif dengan Budidaya Ikan dan Sayur dalam Ember (Budikdamber) sebagai solusi penyediaan bahan pangan dan nutrisi bagi keluarga ditengah pandemi Covid-19, serta adanya peningkatan kemandirian bagi masyarakat yang tinggal di daerah pedesaan maupun diperkotaan dapat memanfaatkan lahan pekarangan yang tidak terlalu luas untuk membudidayakan ikan sekaligus bercocok tanam dengan Teknik Budikdamber.

\section{Daftar Pustaka}

Rachmawati, Rina.2011. peranan bauran pemasaran (marketing mix) terhadap peningkatan penjualan (sebuah kajian terhadap bisnis restoran).jurnal kompetensi teknik 2 (2).

Arif, Abdul. (2020, 12 Agustus). Solusi Ketahanan Pangan Keuarga, Mahasiswa Undip Membuat Budikdamber dengan Aquaponik. http://www.google.com/amp/s/amp.ayos emarang.com/read/2020/08/12/61912/so lusi-ketahanan-pangankeluargamahasiswaundipmembuatbudikdamberdenganaquaponik 
Budikdamber Jadi Solusi Kemandirian Pangan Selama Pandemi Covid-19. (2020, 15 Mei).

https://m.trubus.id/amp/36714/budikda sumber-jadi-solusi-kemandirianpanganselama-pandemi-covid-19

Inilah Tips Cara Menyikapi Era New Normal. (2020, 18 Juni). http://jurnalsecurity.com/inilahtipscaramenyikapi-era-new-normal/ Nursandi, Juli. Budidaya Ikan dalam Ember (BUDIKDAMBER). http://bulelengkab.go.id

Rizky, Fahreza. (2020, 10 Juni). Era New Normal, Jokowi: Beradaptasi dengan Corona Bukan Berarti Kalah. http://nasional.okezone.com/amp/2020/ 06/10/337/2227521/era-new normaljokowiberdaptasi- dengancorona-bukanberartikita- kalah

Saputri, Sherina Annis Dewi,. Dessy Rachmawatie. (2020). Budiday Ikan Dalam Ember: Strategi Keluarga Dalam Rangka Mempertahankan Ketahanan Pangan Ditengah Pandemi Covid-1., Jurnal Ilmu Perikanan Tirtayasa, 2(1). 103 . http://jurnal.untitra.ac.id/index.php/JIPT /articel/view/102-109

Susetya, Ipanna Enggar,. Zulham Apandy Harahap. (2020). Aplikasi Budikdamber (Budidaya Ikan Dalam Ember) Untuk Keterbatasan Lahan Budidaya Di Kota Medan. ABDIMAS TALENTA 3 (2) 2018: $416-420.419$ dan 420. http://jurnal.usu.ac.i 